\title{
In Vitro Digesting Measurement of Cassava Leaves Using Gizzard Fluid and Chicken Duodenum
}

\author{
Ali Mursyid Wahyu Mulyonoํㅡㄹ Engkus Ainul Yakin², Mohammad Affan \\ Azizy Hasibuan ${ }^{3}$. \\ ${ }^{1,2,3}$ Program Study of Animal Husbandry, Faculty of Agriculture \\ Universitas Veteran Bangun Nusantara \\ Corresponding author :alimursyid64@gmail.com
}

\begin{abstract}
Cassava leaves are an alternative feed material that can be a feed material with sufficient protein content. The study aimed to determine the effect of gizzard and duodenal fluids on in vitro digesting measurements of cassava leaves. The study used a Complete Randomized Design (RAL) unidirectional pattern, Variance Analysis (ANOVA) with Duncan's Multiple Range Terst (DMRT) follow-up test using the SPSS application. The study used 4 treatments and 3 repeats: P0: No digestive fluids (controls), P1: Gizzard fluid, P2: Duodenal fluid, P3: A mixture of gizzard and duodenal fluids. The observed variables are the Dry Material Digest Coefficient (KCBK), the Organic Material Digest Coefficient (KCBO), and the Dissolved Protein Digest Coefficient (KCPT). The results of the study that the use of gizzard fluid in in vitro digestion measurements was better in increasing the value of in vitro digestant of cassava leaves. The use of gizzard fluid can increase the digestibility coefficient of organic matter (KCBO) by $21.2160 \%$ and the dissolved protein digest coefficient (KCPT) by $50.4620 \%$.
\end{abstract}

Keyword: cassava leaves, duodenal fluid, Liquid gizzard

\section{Introduction}

One of the factors that determine the success of cultivation efforts is feed. Commercial feed can cost about 60-70\% of the total production cost (Hadadi et al., 2009). Protein content is something that must be considered in the selection of feed materials. The quality of poultry feed is seen from its protein content, if the higher and complete the protein then the better the feed (Sugiyono et al., 2015).

Protein is a very important nutrient for poultry provided through feed. Therefore, it takes feed ingredients that have a high protein source to meet the needs of these nutrients. In general, poultry ration protein is met from animal proteins (fish meal, blood meal etc.) and vegetable protein (peanut bungkil, soybean bungkil etc.) which is relatively expensive. Alternative feed ingredients that can be feed ingredients with sufficient protein content are cassava leaves.

Cassava leaves (Manihot utilissima) are plants that are often found in plantation areas or village environments. Cassava is easy to grow in the deep and even cassava leaves are also used as foodstuffs. However, cassava after harvesting leaves a lot of unused cassava leaf waste so that it can be used as feed material for poultry. Cassava leaf protein content ranges from 25 - 28\% (Sukarman, 2012). The content of toxic compounds 
in the form of cyanide contained in the leaves and skin of cassava is a problem that limits the use of this raw material as a substitute for poultry feed (Stephanie et al., 2013).

The study aimed to determine the effect of gizzard and duodenal fluids on in vitro digesting measurements of cassava leaves.

\section{Materials and Methods}

This research was conducted in February - May 2021 at the Laboratory of the Faculty of Agriculture, Veteran University Bangun Nusantara Sukoharjo. The tools used are plastic, spoon, label paper, measuring pipette, test tube, filter paper, Erlenmeyer, vortex, water bath, blender, centrifuge, scales. The materials used are young cassava leaves, gizzard fluid and chicken broiler duodenum fluid, $\mathrm{HCl}$ solution $0.1 \mathrm{~N}$ and $\mathrm{NaHCO} 31 \mathrm{M}$, aquades solution.

\section{Research methods}

The study used a complete randomized design (RAL) of unidirectional patterns with 4 treatments and 3 repetitions each, so there were 15 units of treatment. The details of the treatment are as follows:

P0: Without digestive fluids (control)

P1: Gizzard fluid

P2: Duodenal fluid

P3: Mixture of gizzard and duodenal fluids

\section{In Vitro Digesting Measurement Procedure}

\section{Procedure P0}

a. g cassava leaf flour is put in $30 \mathrm{ml}$ solution $\mathrm{HCl} 0.1 \mathrm{~N}$ and incluted for 45 minutes.

b. Add a solution of $\mathrm{NaHCO} 31 \mathrm{M}$ as much as $10 \mathrm{ml}$ and inc inclution for 120 minutes.

c. Filter the solution with a filter paper that has been weighed and the filter results are dried for 24 hours at a temperature of $105^{\circ} \mathrm{C}$ and then weighed.

\section{Procedure P1}

a. $3 \mathrm{~g}$ cassava leaf flour is put into $30 \mathrm{ml}$ of HCL solution $0.1 \mathrm{~N}+$ gizzard liquid (from the extraction of 1 piece of gizzard) and incubated for 45 minutes at a temperature of $40^{\circ} \mathrm{C}$.

b. Add $10 \mathrm{ml}$ of $\mathrm{NaHCO} 31 \mathrm{M}$ then incubated for 120 minutes.

c. Filter the solution with a filter paper that has been weighed and the filter results are dried for 24 hours at a temperature of $105^{\circ} \mathrm{C}$ and then weighed.

\section{Procedure P2}

a. $3 \mathrm{~g}$ cassava leaf flour is put into $30 \mathrm{ml}$ of $\mathrm{HCl}$ solution of $0.1 \mathrm{~N}+$ duodenal fluid (from the extraction of 1 duodenum) and incubated for 45 minutes at a temperature of $40^{\circ} \mathrm{C}$.

b. Add a solution of $\mathrm{NaHCO} 31 \mathrm{M}$ as much as $10 \mathrm{ml}$ and incubated for 120 minutes.

c. Filter the solution with a filter paper that has been weighed, and the filter results are dried for 24 hours at a temperature of $105^{\circ} \mathrm{C}$ and then weighed. 


\section{Procedure P3}

a. $\quad 3 \mathrm{~g}$ cassava leaf flour is put into $30 \mathrm{ml}$ of $\mathrm{HCl}$ solution $0.1 \mathrm{~N}+$ gizzard fluid (from extraction of 1 gizzard) + duodenal fluid (from extraction of 1 duodenum) and incubated for 45 minutes at $40 \square \mathrm{C}$.

b. Add $10 \mathrm{ml}$ of $\mathrm{NaHCO} 31 \mathrm{M}$ then incubated for 120 minutes at a temperature of $40^{\circ} \mathrm{C}$. c. Filter the solution with a filter paper that has been weighed, and the filter results are dried for 24 hours at a temperature of $105^{\circ} \mathrm{C}$ and then weighed.

\section{Research Variables}

The variables observed in this study are the Dry Material Digestibility, Organic Material Digestibility, and Crude Protein Digestibility using cassava leaf raw materials.

\section{Dry matter digestability}

$\mathrm{KCBK}=\frac{\text { BK sampel-BK residu }}{\text { BK sampel }} \times 100 \%$

Information:

$\mathrm{KCBK}=$ Dry material digest coefficient $(\%)$

BK sample = Dry weight of the sample $(\mathrm{g})$

$\mathrm{BK}$ residue $=$ Dry weight residue $(\mathrm{g})$

\section{Organic matter digestibility}

$\mathrm{KCBO}=\frac{(\mathrm{BOS} \times \mathrm{KBOS})-(\mathrm{BOR} \times \mathrm{KBOR})}{\mathrm{BOS} \times \mathrm{KBOS}} \times 100 \%$

Information:

$\mathrm{KCBO}=$ Digest coefficient of organic matter $(\%)$

BOS = Sample weight $(\mathrm{g})$

KBOS = Sample organic material content $(\%)$

$\mathrm{BOR}=$ Residual weight $(\mathrm{g})$

$\mathrm{KBOR}=$ Levels of organic residues $(\%)$

\section{Crude protein digestability}

$\mathrm{KCPT}=\frac{(\text { BOS } \times \text { KPTS })-(\text { BOR } \times \text { KPTR }}{(\text { PTS } \times \text { KPTS })} \times 100 \%$

Information:

$\mathrm{KCPT}=$ Dissolved protein digest coefficient $(\%)$

BOS = Sample weight $(\mathrm{g})$

KPTS $=$ Sample dissolved protein levels $(\%)$

BOR = Residual weight $(\mathrm{g})$

KPTR $=$ Residual dissolved protein levels $(\%)$

\section{Data Analysis}

The study used a Complete Randomized Design (RAL) unidirectional pattern, Variance Analysis (ANOVA) with Duncan's Multiple Range Terst (DMRT) follow-up test using the SPSS application. 


\section{Results and Discussions}

\section{Dry matter digestability}

The digestibility of dry ingredients is part of the dry material in the feed digested by animals at a certain level of feed consumption The digestibility of dry ingredients is measured with the aim of knowing the amount of food substances absorbed by the body that is done by analyzing the amount of dry ingredients, both in rations and in feces. Here are the results of KCBK measurements on cassava leaves using gizzard fluid and chicken duodenum.

Tabel 1. Average digest coefficient of dry material cassava leaves.

\begin{tabular}{ccccc}
\hline \multirow{2}{*}{ Replication } & \multicolumn{4}{c}{ Treatment } \\
\cline { 2 - 5 } & P0 $(\%)$ & P1 $(\%)$ & P2 $(\%)$ & P3 $(\%)$ \\
\hline 1 & 18.133 & 21.638 & 18.100 & 17.716 \\
2 & 17.843 & 18.415 & 15.818 & 15.618 \\
3 & 18.889 & 20.267 & 20.899 & 21.291 \\
\hline Average & $18.288^{\mathrm{a}}$ & $20.106^{\mathrm{a}}$ & $18.272^{\mathrm{a}}$ & $18.208^{\mathrm{a}}$ \\
\hline
\end{tabular}

P0: Without digestive fluids (control)

P1: Gizzard fluid

P2: Duodenal fluid

P3: Mixture of gizzard and duodenal fluids

abc on the line shows significant differences $(\mathrm{P}<0,05)$

On Table 1. P1 (gizzard fluid administration) tends to increase the value of dry matter digestibility even though it is statistically insignificant. The use of duodenal fluid (P2) and the mixture of gizzard fluid with duodenum (P3) has no noticeable effect in improving dry digesting when compared to $\mathrm{P} 0$.

This is because, the digestive system in poultry has limitations in digesting coarse fiber. Feed material with a high coarse fiber bladder can affect the digestive process in the digestive organs. Organs will work harder in the digestive process if the content of coarse fiber above tolerance, Because poultry does not have the enzyme selulase to digest coarse fibers. For broilers, the recommended rough fiber content is a maximum of $5 \%$ in rations (Sutrisna, 2011). While the content of coarse fiber found in cassava leaves is $15.80 \%$.

\section{Organic matter digestibility}

The digestability of organic matter in the feed can determine the quality of the feed. Organic materials can produce energy that has an effect on growth and development in livestock (Dinata et al., 2015). Organic matter is an ingredient that produces energy and heat when digested, consisting of carbohydrates, proteins and fats (Saha et al., 2013). Some factors that affect the digestability of organic matter is the content of coarse fiber and mineral feed material. The digestability of organic matter is closely related to the digesting of dry materials, because dry materials consist of organic and inorganic 
materials. Here are the results of $\mathrm{KCBO}$ measurements on cassava leaves using gizzard fluid and chicken duodenum.

Tabel 2. Average digest coefficient of organic material cassava leaves.

\begin{tabular}{ccccc}
\hline \multirow{2}{*}{ Replication } & \multicolumn{4}{c}{ Treatment } \\
\cline { 2 - 5 } & $\mathrm{P} 0(\%)$ & $\mathrm{P} 1(\%)$ & $\mathrm{P} 2(\%)$ & $\mathrm{P} 3(\%)$ \\
\hline 1 & 15.276 & 22.726 & 16.693 & 17.914 \\
2 & 14.975 & 19.548 & 14.371 & 15.821 \\
3 & 16.058 & 21.374 & 19.539 & 21.480 \\
\hline Average & $15.436^{\mathrm{a}}$ & $21.216^{\mathrm{b}}$ & $16.867^{\mathrm{a}}$ & $18.405^{\mathrm{ab}}$ \\
\hline
\end{tabular}

P0: Without digestive fluids (control)

P1: Gizzard fluid

P2: Duodenal fluid

P3: Mixture of gizzard and duodenal fluids

abc on the line shows significant differences $(\mathrm{P}<0,05)$

On table 2. P1 (gizzard) has a noticeable effect in increasing organic matter digestibility values, but is not real different from P3 (a mixture of gizzard and duodenum). The administration of a mixture of gizzard and duodenum cannot increase the value of organic matter digestibility.

The increase in the value of organic matter digestibility due to the role of enzymes in proventriculus in digesting still affects the gizzard which is the channel after. This shows that the increasing value of dry matter digestibility. also has an effect on organic matter digestibility. Organic matter is part of dry materials, so if dry material increases it will increase organic matter, and vice versa (Fathul et al., 2010).

\section{Crude protein digestability}

A dissolved protein is an oligopeptide or amino acid that can be easily absorbed by the digestive system, while a total protein is a measurement of the nitrogen content $(\mathrm{N})$ in the sample (Purwoko, 2006). Here are the results of crude protein digestibility measurements on cassava leaves using gizzard fluid and chicken duodenum.

Tabel 3. Average digest coefficient of dissolved proteins of cassava leaves.

\begin{tabular}{ccccc}
\hline \multirow{2}{*}{ Replication } & \multicolumn{4}{c}{ Treatment } \\
\cline { 2 - 5 } & P0 $(\%)$ & P1 $(\%)$ & P2 $(\%)$ & P3 $(\%)$ \\
\hline 1 & 41.745 & 49.017 & 31.515 & 26.770 \\
2 & 43.309 & 50.418 & 30.171 & 29.447 \\
3 & 41.855 & 51.951 & 27.097 & 32.806 \\
\hline Average & $42.303^{\mathrm{b}}$ & $50.462^{\mathrm{c}}$ & $29.594^{\mathrm{a}}$ & $29.674^{\mathrm{a}}$ \\
\hline
\end{tabular}

P0: Without digestive fluids (control)

P1: Gizzard fluid

P2: Duodenal fluid

P3: Mixture of gizzard and duodenal fluids

abc on the line shows significant differences $(P<0,05)$ 
On table 3. It concludes that the crude protein digestibility value may increase at P1 (gizzard). In the use of duodenum and gizzard and duodenal mixtures, crude protein digestibility values decrease significantly, so it can be stated P2 and P3 cannot increase crude protein digestibility values.

The increasing value of crude protein digestibility in P1 (gizzard) is due to proventiculus (digestive tract before gizzard) producing pepsin enzymes that aid protein digestion. Then continue to the gizzard, in the gizzard takes place the elastic i.e. mechanically digested food. In this case it is concluded that in the gizzard is a continuation of the results of protein digestion that occurs in proventiculus, so in gizzard there may still be pepsin enzymes that digest proteins and increase the value of crude protein digestibility.

\section{Conclusion}

Research concluded that the use of gizzard fluid is better at improving the digestability in vitro of cassava leaves. The use of gizzard fluid can increase the organic matter digestibility by $21.2160 \%$ and crude protein digestibility by $50.4620 \%$.

\section{Reference}

Dinata, D.D., Widiyanto., dan Pujianingsih R.I. 2015. Pengaruh Suplementasi Minyak Biji Kapuk Terhadap Fermentabilitas Ruminal Rumput Gajah pada Sapi Secara In Vitro. Fakultas Pertanian dan Peternakan, Universitas Diponegoro Jurnal Agripet. Vol. 15.

Fathul, F. dan S. Wajizah. 2010. Penambahan Mikromineral Mn dan Cu dalam Ransum terhadap Aktivitas Biofermentasi Rumen Domba secara In Vitro. JJITV. 15(1): 915.

Hadadi, A., Herry, K. T. Wibowo, E. Pramono, A. Surahman, dan E. Ridwan. 2009. Aplikasi Pemberian Maggot Sebagai Sumber Protein Dalam Pakan Ikan Lele Sangkuriang (Clarias sp.) dan Gurame (Osphronemus gouramyLac.). Laporan Tinjauan Hasil Tahun 2008. Balai Pusat Budidaya Air Tawar Sukabumi. Hlm 175 \pm 181 .

Saha U, Sonon L, Hancock D, Hill N, Stewart L, Hesner G, and E. David. 2013. Common Terms Used in Animal Fending and Nutrition. The University of Georgia.

Sugiyono, N., Elindratiningrum dan Primandini, Y. 2015. Determinasi energy metabolis dan kandungan nutrisi hasil samping pasar sebagai potensi bahan pakan lokal ternak unggas. Jurnal Agripet. 15 (1) : 41-45.

Sukarman S. H. 2012. Daun Singkong Adalah Bahan Baku Protein Pakan yang Murah dan Mudah didapat, Jakarta: Balai Pustaka.

Stephanie dan Purwadaria, T. 2013. Fermentasi substrat pada kulit singkong sebagai bahan pakan ternak unggas. Jurnal Wartazoa 23 (1): 15-22.

Sutrisna, R. 2011. Penggunaan Beberapa Tingkat Serat Kasar dalam Ransum Itik Jantan Sedang Bertumbuh. Jurnal Penelitian Pertanian Terapan Vol. 11 (3): 112-118. 